\title{
ANALISIS DISPARITAS WILAYAH DILIHAT DARI PEREKONOMIAN KABUPATEN/KOTA PROVINSI BALI : PENDEKATAN SIGMA DAN BETA KONVERGEN
}

\author{
I Made Guna Juliarta ${ }^{1}$ Ni Putu Wiwin Setyari ${ }^{2}$
}

\section{Article history:}

Submitted:

25 November 2021

Revised:

2 Januari 2022

Accepted:

3 Januari 2022

\section{Keywords:}

Convergence;

Inequality;

Economic Growth;

Sigma Convergence;

Beta Convergence.

\section{Kata Kunci:}

Konvergensi;

Ketimpangan;

Pertumbuhan Ekonomi;

Konvergensi Sigma;

Konvergensi Beta.

\section{Koresponding:}

Fakultas Ekonomi dan Bisnis

Universitas Udayana, Bali, Indonesia

Email:

gunajuliarta03@gmail.com

\author{
Abstract
}

Economic development on the one hand is more oriented towards high economic growth because it can have a direct impact on the real economic sector, it will also have an impact on per capita income, increase consumption and will encourage a better economic structure. As a result of the orientation of high economic growth, it can affect development inequality between regions. This study aims to determine whether there is a decrease in the gap in economic growth every year (convergent sigma) and whether there is an acceleration of economic growth in underdeveloped regions against developed regions (convergent beta) in Bali Province in 2010-2020. By using secondary data and panel data regression analysis. The results of the sigma convergence analysis show that there is a divergence and the analysis of beta convergence does not show the occurrence of convergence of economic growth in districts/cities in the province of Bali. The variabels of Government Expenditure, Investment, and HDI have not been able to encourage convergence.

\begin{tabular}{l} 
Abstrak \\
\hline Pembangunan ekonomi yang berorientasi pada pertumbuhan ekonomi yang \\
tinggi dapat menimbulkan dampak langsung pada sektor ekonomi riil, juga \\
berdampak pada pendapatan perkapita, peningkatan konsumsi dan akan \\
mendorong struktur ekonomi menjadi lebih baik. Akibat dari orientasi \\
pertumbuhan ekonomi tinggi dapat berpengaruh terhadap ketimpangan \\
pembangunan antar wilayah. Penelitian ini bertujuan untuk mengetahui \\
apakah terjadi penurunan kesenjangan pertumbuhan ekonomi setiap tahun \\
(sigma Konvergen) dan apakah terjadi percepatan pertumbuhan ekonomi \\
wilayah tertinggal terhadap wilayah maju (beta konvergen) di Provinsi Bali \\
tahun 2010-2020. Dengan menggunakan data sekunder dan analisis regeresi \\
data panel. Hasil analisis konvergensi sigma menunjukan terjadinya \\
divergensi dan analisis konvergensi beta tidak menunjukan terjadinya \\
konvergensi pertumbuhan ekonomi di Kabupaten/Kota di Provinsi Bali. \\
Variabel Pengeluaran Pemerintah, Investasi, dan IPM ternyata belum \\
mampu mendorong terjadinya konvergensi.
\end{tabular}

Fakultas Ekonomi dan Bisnis Universitas Udayana, Bali, Indonesia ${ }^{2}$ 
Analisis Disparitas Wilayah Dilihat Dari...

I Made Guna Juliarta \& Ni Putu Wiwin Setyari

\section{PENDAHULUAN}

Tujuan lain dari pembangunan ekonomi adalah untuk menghasilkan kesejahteraan masyarakat, kesejahteraan masyarakat dapat juga terlihat melalui meningkatnya pertumbuhan ekonomi dan meratanya distribusi. (Arsyad, 2010) Pembangunan ekonomi biasanya sudah mencakup segala aktivitas ekonomi dan berbagai usaha pemerataan pembangunan dan distribusi pendapatan diseluruh daerah (Sirojuzilam, 2010). Di Indonesia pertumbuhan ekonomi nasional ditopang oleh perekonomian yang ada di 33 provinsi diseluruh Indonesia yang memiliki berbagai macam karakteristik ekonomi. Pertumbuhan ekonomi di masing-masing daerah meliputi berbagai aspek. Hambatan yang sering muncul di daerah saat pertumbuhan ekonomi terjadi adalah disparitas pembangunan. Pendekatan pembangunan yang lebih mengutamakan pertumbuhan ekonomi justru selama ini menimbulkan berbagai masalah ekonomi seperti, pengangguran, kemiskinan dipedesaan, ketidakseimbangan struktural dan ketimpangan distribusi pendapatan (Sjahril dalam Kuncoro, 2003:9).

Emilia \& Imelia (2006) menyebutkan yang menyebabkan terjadinya disparitas ekonomi adalah konsentrasi kegiatan ekonomi wilayah, investasi, kurangnya mobilitas factor produksi, perbedaan sumber daya alam dan tidak lancarnya perdagangan antar wilayah. Perlu adanya pemerataan pembangunan dan distribusi pendapatan yang bertujuan untuk menguranngi kemiskinan. Tanpa adanya pemerataan ekonomi akan mengakibatkan terjadinya pelebaran jurang pemisah antar kelompok masyarakat, sebaliknya kemiskinan suatu daerah akan meningkat apabila pemerataan ekonomi tanpa dibarengi dengan pertumbuhan ekonomi (Rubiarko, 2013)

Hasil studi dari Kuncoro (2004) menyebutkan terdapat beberapa faktor yang menyebabkan terjadinya perbedaan laju pertumbuhan ekonomi antar daerah antara lain investor yang lebih memilih untuk menginvestasikan modalnya ke daerah yang memiliki infrastruktur yang lengkap seperti listrik, telekomunikasi, jaringan jalan, tenaga kerja yang terampil, selain itu redistribusi pembagian pendapatan dari pemerintah pusat ke daerah menjadi faktor terjadinya ketimpangan pertumbuhan ekonomi. Pembangunan pada dasarnya adalah upaya yang dilaksanakan secara terprogram dan komperhensif untuk mencapai kesejahteraan seluruh masyarakat. Pertumbuhan ekonomi Provinsi Bali beberapa kali sempat berada diatas rata-rata pertumbuhan ekonomi nasional yang ditopang oleh pertumbuhan pertumbuhan ekonomi per kabupaten yang berada di Provinsi Bali yang turut memberikan sumbangsih dalam menggerakan roda perekonomian Provinsi Bali. Pertumbuhan ekonomi Bali dari Tahun 20112019 mengalami pergerakan yang fluktuatif namun tidak terlalu signifikan.

Pertumbuhan ekonomi Bali pada tahun 2011 tercatat sebesar 6,66 persen, mengalami kenaikan pada tahun 2012 sebesar 6,96 persen. Namun pada tahun 2013 kembali lagi mengalami penurunan namun tidak terlalu signifikan yaitu sebesar 6,69 persen. Tahun 2014 kembali mengalami kenaikan sebesar 6,73 persen dan kembali mengalami 
Analisis Disparitas Wilayah Dilihat Dari...

I Made Guna Juliarta \& Ni Putu Wiwin Setyari

penurunan pada tahun 2015 sebesar 6,03 persen. Tahun 2016 kembali mengalami kenaikan sebesar 6,33 persen namun pada tahun 2017 kembali mengalami penurunan sebesar 5,56 persen. Hal yang sama kembali lagi terulang yaitu pada tahun 2018 mengalami kenaikan sebesar 6,33 persen dan kembali lagi mengalami penurunan sebesar 5,63 persen pada tahun 2019 .

Pertumbuhan ekonomi tertinggi dari tahun 2011 sampai tahun 2019 didominasi oleh Kabupaten Badung dan Kota Denpasar dengan rata-rata pertumbuhan masing-masing sebesar 6,81 persen dan 6,76 persen, sementara rata-rata pertumbuhan ekonomi paling rendah dicapai oleh kabupaten Karangasem yaitu sebesar 5,79 persen. Tahun 2020 sedang terjadi wabah virus Covid 19 yang menyebabkan pertumbuhan ekonomi Provinsi Bali berada pada angka -9,31 persen. Kemerosotan ekonomi tertinggi terjadi pada Kabupaten Badung yaitu sebesar -16.52 persen. yang disebabkan karena Kabupaten Badung mengandalkan sektor pariwisata sebagai sektor utama penunjang perekonomian yang mana pada saat wabah virus Covid 19 melarang destinasi wisata ataupun akomodasi wisata untuk membuka usahanya.

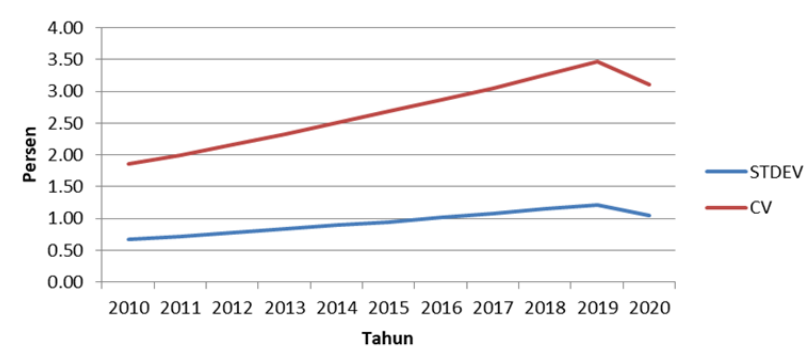

Sumber: Badan Pusat Statistik Provinsi Bali, 2020 Gambar 1.

Trend Dispersi PDRB Perkapita Provinsi Bali 20102020
PDRB perkapita menggambarkan jumlah pendapatan yang diterima penduduk dalam jangka waktu 1 tahun. Berdasarkan grafik diatas trend dispersi PDRB perkapita Provinsi Bali menggambarkan trend peningkatan dari tahun 2010 sampai tahun 2019. Peningkatan trend dispersi PDRB perkapita tersebut berarti bahwa terdapat variasi angka PDRB yang tinggi yang memiliki arti bahwa persebaran pendapatan perkapita tidak merata disetiap daerah. Disetiap daerah memiliki beraneka ragam potensi yang akan bisa menghasilkan pendapatan bagi daerah tersebut. Kabupaten Badung adalah kabupaten yang mengandalkan pariwisata sebagai penggerak utama sector perekonomian, namun pada tahun 2020, seperti data yang ditampilkan diatas menunjukan penurunan angka dispersi yang berarti angka PDRB semakin homogen akibat dari situasi global yang mengalami pandemi Covid 19 yang melarang warga di masing-masing negara untuk berwisata ke Negara lain.

Pendekatan yang diperlukan untuk memprediksi terjadinya kesetaraan pertumbuhan ekonomi antar daerah di Provinsi Bali adalah pendekatan konvergensi. Konvergensi ini digunakan untuk melihat kapan kesetaraan ekonomi antar daerah atau negara itu terjadi (Schmitt \& Starke, 2011; Dekiawan, 2014). Konvergensi juga dijelaskan sebagai kondisi dimana terjadinya kemiripan ekonomi antar daerah (Barro \& Sala-I-Martin, 1992; Dana, 2018). Kondisi konvergen dapat dicapai dalam waktu yang berbeda-beda oleh setiap negara atau daerah, tergantung kondisi masing-masing daerah atau negara. Cabral \& Castellanos-Sosa 
(2019) menyebutkan bahwa tingkat konvergensi di eropa mengalami penurunan ketika mengalami krisis global. Menurut hasil penelitian dari Blížkovský (2012) menyebutkan bahwa negara di Uni Eropa untuk mengurangi disparitas memerlukan waktu yang lama. Di negara berkembang terjadi perbedaan, di negara India terjadi percepatan konvergensi saat pembagian kelompok pendapatan (Agarwalla \& Pangotra, 2011). Di Negara Afrika Djennas \& Ferouani (2014) mengatakan bahwa berdasarkan pada sigma dan beta konvergen, tingkat konvergensi membutuhkan waktu yang lama. Dari beberapa penelitian diatas, menunjukan bahwa konvergensi masih diperlukan untuk mengurangi disparitas antara daerah yang kaya dengan yang miskin.

.Penelitian mengenai disparitas sebelumnya telah dilakukan oleh Utami (2011) yang menguji terjadinya disparitas di Provinsi Bali dengan hanya menghitung indeks Williamson dan menguji apakah hipotesis Kuznet terjadi di Provinsi Bali. Penelitian lain juga dilakukan oleh Gama (2012) yang menguji konvergensi pertumbuhan ekonomi di Provinsi Bali namun penelitian tersebut tidak memaparkan prediksi waktu yang dibutuhkan untuk mencapai kesetaraan dan kecepatan pertumbuhan ekonomi yang diperlukan daerah tertinggal untuk mengejar pertumbuhan ekonomi daerah kaya.

Maka dari itu pendekatan konvergensi ini sangat diperlukan untuk mendukung penelitian ini untuk mengetahui disparitas pembangunan ekonomi di kabupaten/kota di Provinsi Bali serta untuk melihat waktu yang dibutuhkan untuk mencapai kesetaraan ekonomi antar kabupaten dan kota di Provinsi Bali juga dapat digunakan untuk melihat kebijakan yang diambil oleh pemerintah daerah dalam rangka mengurangi disparitas antar daerah. Dengan demikian maka penelitian ini bertujuan untuk mengetahui apakah terjadi penurunan kesenjangan ekonomi setiap tahun dan apakah terjadi percepatan pertumbuhan daerah pertumbuhan ekonomi rendah terhadap daerah pertumbuhan ekonomi maju di Provinsi Bali.

\section{METODE PENELITIAN}

Penelitian ini menggunakan metode kuantitatif yang berbentuk deskriptif dan asosiatif serta bertujuan untuk mengetahui variabel apa saja yang berpengaruh terhadap pertumbuhan ekonomi pada konsep beta konvergen di Provinsi Bali. Variabel yang digunakan adalah pengeluaran pemerintah, investasi, dan indeks pembangunan manusia sebagai variabel independen sedangkan pertumbuhan ekonomi sebagai variabel dependen. Pengeluaran pemerintah, investasi, dan indeks pembangunan manusia diperkirakan berpengaruh terhadap pertumbuhan ekonomi pada konsep beta konvergen sedangkan pada konsep sigma konvergen untuk mengetahui tingkat disparitas antar wilayah apakah mengalami peningkatan atau tidak dan tipologi klassen untuk mengetahui pola pertumbuhan ekonomi di kabupaten/kota di Provinsi Bali.

\begin{tabular}{lccr}
\multicolumn{1}{c}{ Lokasi } & penelitian & ini & berada \\
dikabupaten/kota & di & Provinsi & Bali. \\
Pertimbangan & memilih & Provinsi & Bali \\
berdasarkan & permasalahan & pertumbuhan
\end{tabular}


Analisis Disparitas Wilayah Dilihat Dari...

I Made Guna Juliarta \& Ni Putu Wiwin Setyari

ekonomi yang kurang merata. Data yang digunakan di dalam penelitian ini adalah data Panel selama periode 2010-2020. Pertimbangan ini diambil karena data rentang waktu 10 tahun bisa menggambarkan pola pertumbuhan ekonomi disuatu wilayah selain itu pertimbangan lainnya adalah ketersediaan data yang disediakan BPS. Penelitian ini merupakan penelitian mengenai disparitas wilayah yang dilihat dari perekonomian kabupaten/kota di Provinsi Bali melalui pendekatan beta konvergen dan sigma konvergen.

Penelitian ini melihat tingkat disparitas daerah berdasarkan pertumbuhan ekonomi solow dengan pendekatan beta konvergen dan sigma konvergen. Sigma konvergen digunakan untuk melihat disparitas berdasarkan pada Unweighted Coefficient of Variation. Sementara, beta konvergen digunakan untuk melihat disparitas berdasarkan pada fakor-faktor yang mempengaruhi pertumbuhan ekonomi berdasarkan pada model pertumbuhan ekonomi Solow. Faktor-faktor pertumbuhan ekonomi yang digunakan meliputi pengeluaran pemerintah, investasi, indeks pembangunan manusia

Pengujian konvergensi absolut secara regional menggunakan data panel pertumbuhan pendapatan sebagai variabel independen dan tingkat pendapatan awal sebagai variabel independen. Untuk dapat melihat konvergensi absolut dapat menggunakan persamaan sebagai berikut:

$\triangle \ln P D R B_{\text {it }}=\beta_{1} \Delta \ln P D R B_{1_{1} t-1}+\Delta u_{\text {it }} \ldots \ldots$ (

Keterangan: $\beta_{1} \quad=$ Kecepatan konvergensi atau persentase ketimpangan yang tertutupi sepanjang tahun

$P D R B_{\text {it }} \quad=$ PDRB perkapita ADHK 2010 kabupaten/kota ke-i pada tahun ke-t

$P D R B_{\text {it }-1}=$ PDRB perkapita ADHK 2010 kabupaten/kota ke-i pada tahun ke-(t-1).

Konvergensi beta absolute terjadi apabila estimasi $\beta$ adalah signifikan dan bernilai negative. Dengan demikian maka dapat disusun hipotesis untuk menguji persamaan diatas sebagai berikut:

Ho $=\beta \geq 0$ berarti bahwa tidak ada konvergensi absolut perekonomian di kabupaten/kota di Provinsi Bali pada periode 2010-2020

$\mathrm{H}_{1}=\beta \leq 0$ berarti bahwa terjadi konvergensi absolut perekonomian di kabupaten/kota di Provinsi Bali pada periode 2010-2020

Konvergensi beta conditional yaitu konvergensi yang dihitung menggunakan pendapatan awal dari suatu daerah dan juga faktor-faktor lain yang dapat mempengaruhi konvergensi perekonomian. untuk menjelaskan konvergensi beta kondisional digunakan persamaan sebagai berikut:

$\Delta \ln P D R B_{i t}=\beta_{1} \Delta \ln P D R B_{i_{i} t-1}+\beta_{1} \Delta \ln P P_{\mathrm{i}_{j} t}+$ $\beta_{1} \Delta \ln I N V E S_{i, t}+\beta_{1} \Delta \ln I P M_{\mathrm{i}, \mathrm{t}} \ldots \ldots \ldots \ldots \ldots$ (2)

Keterangan

$\triangle \ln P D R B_{\text {it }}=$ PDRB perkapita ADHK 2010 kabupaten/kota ke-i pada tahun ke-t 


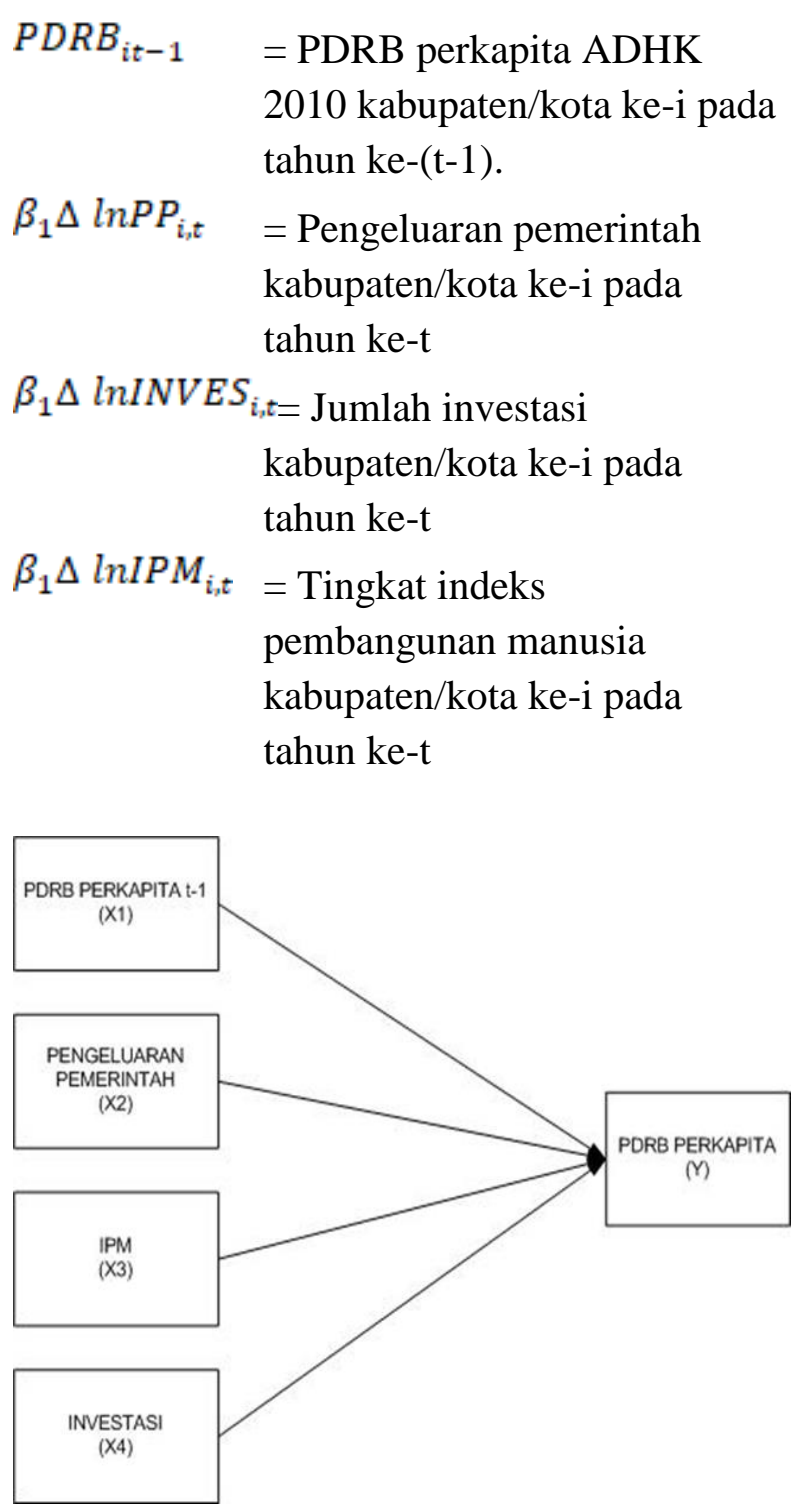

Gambar 2.

Kerangka Konsep Penelitian

Kerangka konsep penelitian berikut ini memperlihatkan keterkaitan variabel independen dan variabel dependen, dimana variabel dependent adalah PDRB Perkapita, sementara variabel independen meliputi PDRB Perkapita t-1, Pengeluaran Pemerintah, Indeks Pembangunan Manusia, dan Investasi.

\section{HASIL DAN PEMBAHASAN}

Hasil Hitung Konvergensi Sigma. Berdasarkan tujuan penelitian yaitu mengidentifikasi tingkat disparitas di Provinsi Bali berdasarkan konsep sigma konvergen akan dibahas selanjutnya. Tolok ukur tingkat disparitas dengan menggunakan sigma konvergen dihitung melalui Unweighted Coefficient of Variation.

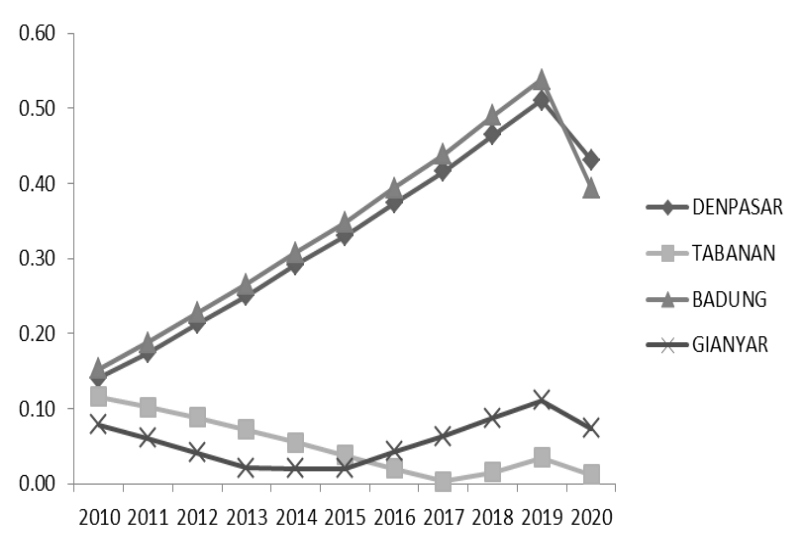

Sumber: Data diolah, 2021

Gambar 3.

Hasil Perhitungan Unweighted Coefficient of Variation

Gambar 3 menjelaskan mengenai tingkat disparitas Unweighted Coefficient of Variation di Kota Denpasar, Kabupaten Badung, Gianyar, dan Tabanan tahun 20102020. Hasil Unweighted Coefficient of Variation menunjukan bahwa pada tahun 2010-2019 pada Kabupaten Badung dan Kota Denpasar menunjukan tren peningkatan disparitas yaitu ditandai dengan semakin menjauhi nilai 0 (nol) namun pada tahun 2020 secara serempak terjadi penurunan di kedua kabupaten tersebut. Dua Kabupaten 
berikutnya yaitu Kabupaten Tabanan dan Gianyar terjadi tren penurunan disparitas ditandai dengan grafik dari tahun 2010-2020 semakin mendekati 0 (nol).

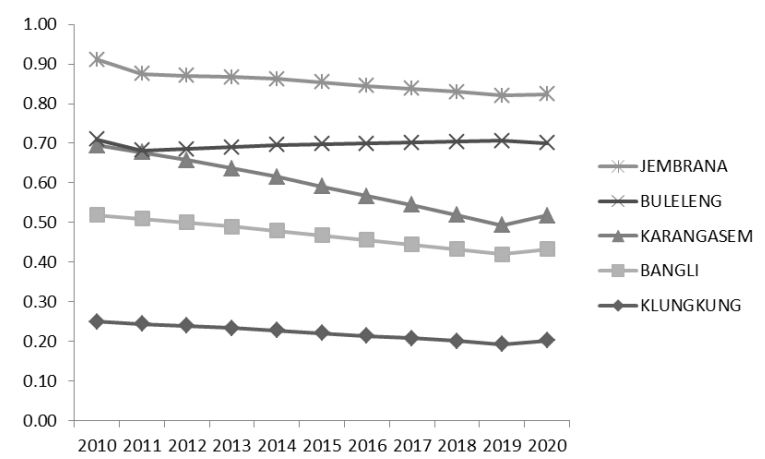

Sumber: Data diolah, 2021

Gambar 4.

Hasil Perhitungan Unweighted Coefficient of Variation

Lima kabupaten di Provinsi yaitu Kabupaten Jembrana, Buleleng, Karangasem, Bangli dan Klungkung secara keseluruhan masih mejauhi 0 (nol). Kabupaten Karangasem pernah mengalami penurunan ditahun 2010 sebesar 0,70 menjadi 0,50 ditahun 2019, namun ditahun 2020 mengalami peningkatan kembali. Begitu pula dengan Kabupaten Bangli yang secara trend grafik dari tahun 2010 ke 2019 mengalami penurunan namun di tahun 2020 juga mengalami peningkatan. Secara keseluruhan ke lima kabupaten diatas dapat dilihat berdasarkan grafik memiliki trend menjauhi angka 0 (nol).

Hasil Hitung Konvergensi Beta. Konvergensi beta absolut adalah kondisi dimana terjadi kemiripan pada struktur ekonomi, kondisi demografi dan tingkat tabungan pada suatu negara atau wilayah.
Menganalisis konvergensi absolut adalah dengan cara mengestimasi model ketika hanya pendapatan awal periode menjadi variabel penjelas bagi pertumbuhan ekonomi. Hasil pengujian dapat dilihat pada Tabel 1 .

Tabel 1.

Estimasi Konvergensi Beta Absolut

\begin{tabular}{|c|c|c|c|c|}
\hline Variable & Coefficient & Std. Error & $\mathrm{t}$-Statistic & Prob. \\
\hline $\mathrm{C}$ & 95.84109 & 23.4871 & 4.080579 & 0.0001 \\
\hline $\operatorname{LnPDRB}_{1, \mathrm{t}-1}$ & 0.910465 & 0.02274 & 40.03096 & 0 \\
\hline R-squared & 0.958146 & \multicolumn{2}{|c|}{ Mean dependent var } & 1035.83 \\
\hline Adjusted R-squared & 0.957548 & \multicolumn{2}{|c|}{ S.D. dependent var } & 20.9258 \\
\hline S.E. of regression & 4.311518 & \multicolumn{2}{|c|}{ Akaike info criterion } & 5.78784 \\
\hline Sum squared resid & 1301.243 & \multicolumn{2}{|c|}{ Schwarz criterion } & 5.85108 \\
\hline Log likelihood & -206.362 & \multicolumn{2}{|c|}{ Hannan-Quinn criter. } & 5.81302 \\
\hline F-statistic & 1602.478 & \multicolumn{2}{|c|}{ Durbin-Watson stat } & 1.33202 \\
\hline $\operatorname{Prob}(\mathrm{F}$-statistic) & 0 & & & \\
\hline
\end{tabular}

\section{Sumber: Data diolah, 2021}

Berdasarkan hasil pengujian diatas dapat dilihat bahwa nilai konstanta sebesar 95.841 memiliki arti bahwa PDRB perkapita tahun penelitian meningkat sebesar 95.841 persen dengan asumsi variabel lain konstan. Nilai koefisien variabel LnPDRB1,t-1 sebesar 0.910465 memiliki arti bahwa variabel LnPDRB1,t-1 naik sebesar 1 persen maka akan meningkatkan PDRB perkapita ditahun penelitian sebesar 0.910465 persen dengan asumsi variabel lain konstan. Probabilitas variabel LnPDRB1,t-1 sebesar 0.0000 lebih kecil dibandingkan $\alpha=0.05$ yang berarti bahwa variabel tersebut berpengaruh secara signifikan terhadap PDRB perkapita. Berdasarkan nilai koefisien LnPDRB1,t-1 kecepatan konvergensi suatu wilayah yaitu ketimpangan yang terkurangi sebesar 9 persen tiap tahunnya dengan lama waktu yang 
Analisis Disparitas Wilayah Dilihat Dari...

I Made Guna Juliarta \& Ni Putu Wiwin Setyari

dibutuhkan untuk menutupi setengah kesenjangan PDRB Perkapita sebanyak 7.38 tahun. Secara keseluruhan maupun individu, variabel independen berpengaruh terhadap variabel dependen berpengaruh secara signifikan dengan probabilitas 0.0000 lebih kecil dari $\alpha=0.05$.

Asumsi dari konvergensi beta kondisional adalah antar wilayah yang memiliki ketidaksamaan karakteristik structural wilayah, sehingga konvergensi dipengaruhi oleh hal tersebut. Ini menjadikan konvergensi beta kondisional perlu ditambahkan variabel penjelas yang diperkirakan akan berpengaruh terhadap pertumbuhan ekonomi. Dalam penelitian ini ditambahkan variabel Pengeluaran Pemerintah, Indeks Pembangunan Manusia, dan Investasi. Hasil pengujian dapat dilihat pada Tabel 2.

Tabel 2.

Hasil Estimasi Konvergensi Beta Kondisional

Variable Coefficient Std. Error t-Statistic Prob.

\begin{tabular}{lrrrr}
\hline \hline & & & & \\
\multicolumn{1}{c}{ C } & 1820.78 & 367.346 & 4.956574 & 0 \\
\multicolumn{1}{c}{ LnPDRB $_{\mathrm{i}, \mathrm{t}-1}$} & 1.08702 & 1.3285 & 0.818233 & 0.4161 \\
$\quad$ LnPP $_{\mathrm{i}, \mathrm{t}}$ & 1.05431 & 1.20139 & 0.877573 & 0.3833 \\
\multicolumn{1}{c}{ LnINVES $_{\mathrm{i}, \mathrm{t}}$} & 0.044014 & 0.02667 & 1.650051 & 0.1036 \\
$\quad$ LnIPM $_{\mathrm{i}, \mathrm{t}}$ & 0.120742 & 0.04194 & 2.879105 & 0.0053 \\
& & & & \\
\hline \hline & & & \\
R-squared & 0.567509 & Mean dependent var & 4302.29 \\
Adjusted R-squared & 0.541689 & S.D. dependent var & 68.1141 \\
S.E. of regression & 46.11237 & Akaike info criterion & 10.567 \\
Sum squared resid & 142465.5 & Schwarz criterion & 10.7251 \\
Log likelihood & -375.41 & Hannan-Quinn criter. & 10.6299 \\
F-statistic & 21.97913 & Durbin-Watson stat & 0.22506 \\
Prob(F-statistic) & 0 & & \\
& & & \\
\hline
\end{tabular}

Sumber: Data diolah, 2021
Berdasarkan Tabel 2 dapat dilihat bahwa nilai konstanta sebesar 1820.78 memiliki arti bahwa PDRB perkapita tahun penelitian meningkat sebesar 1820.78 persen dengan asumsi variabel lain konstan. Nilai koefisien LnPDRBi,t-1 sebesar 1.08702 memiliki arti bahwa LnPDRBi,t-1 naik sebesar 1 persen maka akan meningkatkan PDRB perkapita ditahun penelitian sebesar 1.08702 persen dengan asumsi variabel lain konstan. Probabilitas dari variabel LnPDRBi,t-1 sebesar 0.4161 lebih besar dari $\alpha=0.05$ yang berarti variabel LnPDRBi,t-1 tidak berpengaruh secara signifikan terhadap PDRB perkapita. Hal ini berbeda dengan hasil estimasi konvergensi beta absolut yang menunjukan variabel ini berpengaruh secara signifikan terhadap PDRB perkapita. Selanjutnya nilai koefisien variabel LnPPi,t sebesar 1.0541 memiliki arti bahwa setiap variabel LnPPi,t naik sebesar 1 persen maka akan menaikan PDRB Perkapita sebesar 1.0541 persen dengan asumsi variabel lain konstan. Namun variabel tersebut tidak secara signifikan mempengaruhi karena nilai probabilitas sebesar 0.3833 lebih besar dari $\alpha=0.05$.

Berikutnya yaitu variabel LnINVESi,t yang memiliki nilai koefisien 0.044014 yang berarti bahwa setiap kenaikan variabel LnINVESi,t sebesar 1 persen maka akan menaikan PDRB perkapita sebesar 4.401 persen dengan asumsi variabel lain konstan. Nilai probabilitas variabel LnINVESi,t sebesar 0.1036 lebih kecil dari $\alpha=0.05$ yang berarti tidak signifikan mempengaruhi PDRB perkapita. Variabel yang terakhir adalah LnIPMi,t yang memiliki koefisien sebesar 0.120742 yang berarti bahwa setiap 
peningkatan 1 poin pada variabel LnIPMi,t maka akan meningkatkan PDRB perkapita sebesar 1.20742 persen dengan asumsi variabel konstan. Nilai probabilitas variabel LnIPMi,t sebesar 0.0053 lebih kecil dibandingkan $\alpha=0.05$ yang berarti bahwa variabel Indeks Pembangunan Manusia berpengaruh signifikan terhadap PDRB perkapita.

\section{SIMPULAN DAN SARAN}

Pada analisis sigma konvergen terjadi tren kenaikan disparitas antar wilayah yang ditunjukan dari hasil perhitungan Unweigthed Coefficient of Variation yang mendapatkan hasil meningkat dari tahun ke tahun. Peningkatan paling besar terjadi di Kota Denpasar dan Kabupaten Badung.Hasil analisis konvergensi beta absolut maupun kondisional menunjukan bahwa tidak terjadi konvergensi di Provinsi Bali pada tahun penelitian. Variabel Pengeluaran Pemerintah, Investasi dan Indeks Pembangunan Manusia belum mampu mendorong untuk terjadinya konvergensi.

Kelemahan penelitian ini adalah variabel-variabel yang digunakan masih belum signifikan mempengaruhi variabel independen. Selain itu penelitian ini juga belum memasukan konsep isu spasial jarak antar daerah dalam menganalisis beta konvergen sebagai alternatif dalam melihat konvergensi. Saran yang dapat diberikan dari penelitian ini adalah pemerintah harus berupaya meningkatkan kapasitas ekonomi di masing-masing wilayah sesuai dengan potensi dan karakteristik yang dimiliki wilayah tersebut. Variabel Indeks Pembangunan Manusia yang paling berpengaruh secara signifikan dari ketiga variabel, oleh karena itu pemerintah harus memperhatikan kualitas sumber daya manusia sebagai faktor utama dari pemerataan pembangunan di Provinsi Bali. Peningkatan kualitas hidup ini akan memberikan pengaruh positif pada kemampuan daerah untuk memiliki kesejahteraan yang sama dengan daerah lainnya.

\section{REFERENSI}

Agarwalla, A., \& Pangotra, P. (2011). Regional Income Disparities in India and Test for Convergence - 1980 to 2006. Research and Publications, 1-22.

Arsyad, L. (2010). Ekonomi Pembangunan. Unit Penerbit dan Percetakan STIM YKPN Yogyakarta.

Badan Pusat Statistik Provinsi Bali. (2020). PDRB Perkapita Atas Dasar harga Berlaku Kabupaten/Kota di Provinsi Bali (Ribu Rupiah), 2018-2020. Retrieved from: https://bali.bps.go.id/indicator/52/172/1/pdrbperkapita-kabupaten-kota-di-provinsibali.html

Barro, R. J., \& Sala-I-Martin, X. (1992). Convergence. Journal of Political Economy, 223-251. https://doi.org/10.1086/261816

Blížkovský, P. (2012). Regional disparities and convergences in the European Union. Acta Universitatis Agriculturae et Silviculturae Mendelianae Brunensis, 60(4), 59-70. https://doi.org/10.11118/actaun201260040059

Cabral, R., \& Castellanos-Sosa, F. A. (2019). Europe's income convergence and the latest global financial crisis. Research in Economics, 73(1), 23-34. https://doi.org/10.1016/j.rie.2019. 01.003

Dana, B. S. (2018). Penerimaan Dan Belanja Pemerintah Daerah Di Indonesia: Analisis Sigma Konvergen Dan Beta Konvergen. Simposius Nasional Keuangan Negara, 899916.

Dekiawan, H. (2014). Konvergensi Penerimaan Dan Pengeluaran Pemerintah Provinsi Di 
Analisis Disparitas Wilayah Dilihat Dari...

Indonesia: Pendekatan Data Panel Dinamis Spasial. Buletin Ekonomi Moneter Dan Perbankan, 17(1), 99-128. https://doi.org/10.21098/bemp.v17i1.52

Dewi, I. A. I. U (2014). Analisis Ketimpangan Pembangunan Antara Kabupaten/Kota Di Provinsi Bali. E-Jurnal Ekonomi Dan Bisnis Universitas Udayana, 3(2), 68-80.

Djennas, M., \& Ferouani, B. (2014). Growth and Income Convergence in Africa. Journal of Economics and Development Studies, 2(4). https://doi.org/10.15640/jeds.v2n4a5

Emilia, \& Imelia. (2006). Modul Ekonomi Regional. Fakultas Ekonomi Universitas Jambi, 17-19.

Gama, A. S. (2012). Disparitas dan Konvergensi Produk Domestik Regional Bruto (PDRB) Perkapita Antar Kabupaten/Kota Di Provinsi Bali. INPUT Jurnal Ekonomi Dan Sosial, 2(1), 38-48.

Kuncoro, M. (2004). Otonomi dan Pembangunan Daerah; Reformasi Perencanaan, Strategi dan Peluang. ERLANGGA.

Rubiarko, S. I. (2013). Analisis Faktor-faktor yang Mempengaruhi Disparitas Pendapatan di Provinsi Jawa Timur Tahun 2008-2011. Jurnal Ilmiah Mahasiswa FEB Universitas Brawijaya, 1(2), 1-14.

Schmitt, C., \& Starke, P. (2011). Explaining convergence of oecd welfare states: A conditional approach. Journal of European Social Policy, 21(2), 120-135. https://doi.org/10.1177/0958928710395049

Sirojuzilam. (2010). Regional: Pembangunan, Perencanaan, dan Ekonomi. USU PRESS. 